\title{
Article \\ Seeking the Pressure Points: Catalysing Low Carbon Changes from the Middle-Out in Offices and Schools
}

\author{
Catherine Willan ${ }^{1, *(\mathbb{D}}$, Kathryn B. Janda ${ }^{2}$ and David Kenington ${ }^{2}$ \\ 1 Institute for Sustainable Resources, University College London, Central House, 14 Upper Woburn Place, \\ London WC1H 0NN, UK \\ 2 Energy Institute, University College London, Central House, 14 Upper Woburn Place, London WC1H 0NN, \\ UK; k.janda@ucl.ac.uk (K.B.J.); david.kenington.16@ucl.ac.uk (D.K.) \\ * Correspondence: catherine.willan.14@ucl.ac.uk
}

Citation: Willan, C.; Janda, K.B.; Kenington, D. Seeking the Pressure Points: Catalysing Low Carbon Changes from the Middle-Out in Offices and Schools. Energies 2021, 14, 8087. https://doi.org/10.3390/ en14238087

Academic Editors: Carolyn S. Hayles and Wadim Strielkowski

Received: 30 September 2021 Accepted: 29 November 2021 Published: 2 December 2021

Publisher's Note: MDPI stays neutral with regard to jurisdictional claims in published maps and institutional affiliations.

Copyright: (c) 2021 by the authors. Licensee MDPI, Basel, Switzerland. This article is an open access article distributed under the terms and conditions of the Creative Commons Attribution (CC BY) license (https:// creativecommons.org/licenses/by/ $4.0 /)$.

\begin{abstract}
Non-domestic buildings are frequently characterised as resistant to top-down low-carbon and energy-efficiency policy. Complex relationships amongst building stakeholders are often blamed. "Middle actors" - professionals situated between policymakers and building users—can use their agency and capacity to facilitate energy and carbon decision-making from the "middle-out". We use semi-structured interviews with expert middle actors working with schools and commercial offices, firstly, to explore their experience of energy and low-carbon decision-making in buildings and, secondly, to reflect on the evolution of middle actors' role within it. Our exploratory findings suggest that a situated sensitivity to organisational "pressure points" can enhance middle actors' agency and capacity to catalyse change. We find shifts in the ecology of the "middle", as the UK's Net Zero and Environmental, Social and Governance (ESG) agendas pull in new middle actors (such as the financial community) and issues (such as wellbeing and social value) to non-domestic buildings. These issues may work in reinforcing ways with organisational pressure points. Policy should capitalise on this impetus by looking beyond the physicality of individual buildings and engage with middle actors at a systemic level. This could create greater synergies with organisational concerns and strategies of building stakeholders.
\end{abstract}

Keywords: non-domestic buildings; middle actors; middle-out perspective; energy; carbon; ESG; energy policy

\section{Introduction}

Non-domestic buildings are a daunting challenge to address for low-carbon policymakers. Efforts to create new low-carbon non-domestic buildings have been subject to many varied and interrelated problems [1]. The sector's complexity derives from a huge variety of building forms, activities, and stakeholders that make it distinct from its domestic counterpart [2] to such an extent that it may not merit the term of "sector" [3]. Added to this, professionals involved in non-domestic buildings may have little interest in accumulating knowledge on how buildings work in practice, nor is it mandated that they should [4]. As such, policies to encourage decision-makers to take account of energy efficiency and carbon emissions from buildings struggle to reach those they intend to [5]. Therefore, there is a need to understand this "sector" in new ways if we are to understand more about why it is so difficult to define and reach, and what lies behind its stakeholders' choices around energy and carbon. Despite this need, stakeholder interactions and decision criteria in building energy are still under-researched [6].

The UK's situation is important in this context. In common with the rest of Europe, significant efforts need to be made in the UK to reduce the carbon emissions from buildings, including through massively increased levels of retrofit $[7,8]$. The UK buildings sector is often deemed to lag behind other countries in reducing its environmental footprint, not because of any lack of available technology, but because of deeply-embedded institutional 
and behavioural barriers [9]. Whilst building researchers and policymakers have over many years grappled with these issues with varying levels of attention and limited success, the UK government's commitment to Net Zero made in 2019 has brought the problem of reducing carbon emissions from the building stock into sudden and sharper focus. Given that non-domestic buildings contribute to around 4\% of the UK's national carbon account [10], overcoming these persistent barriers is no longer a concern confined just to building specialists but part of what should be a coordinated national approach to transform the building stock. With the proliferation of Net Zero and carbon neutral rating schemes [11], commitments and initiatives from companies and industry bodies [12,13], and interest in building emissions in the public sector [14], there is also a clear need for practical insights as to what might drive decision-making towards action.

The "Middle-Out Perspective" (MOP) is a useful and innovative window into the complexity of decision-making in non-domestic buildings. Janda and Parag $[15,16]$ have made the case that "middle actors" between policymakers (at the top) and energy users (at the bottom), have agency and capacity to exert their own influence by enabling, mediating, and aggregating energy-related decisions. These actors also have the potential to provide us with insights as to how they influence stakeholder decisions, and how they experience the decision-making processes of those with whom they interact around energy-related technologies. Previous studies have done much to problematise the complexities of energy efficiency and low-carbon transition in non-domestic buildings. Engaging with middle actors who navigate these complexities on a daily basis as part of their professional roles could help clarify pathways through this complexity for policymakers and future research. Finding such pathways is a necessity if the UK is to meet its carbon goals.

Our paper sets out the findings of exploratory interviews with expert sustainability professionals, who all represent different kinds of "middle actors" in UK non-domestic buildings. The research was designed to contribute to a European project, having already published 'Building Market Briefs' of domestic building sectors in five countries, and wishing to develop a similar process for non-domestic buildings [17]. As a pilot test, we focused on two particular non-domestic building sub-sectors-schools and offices-and tailored our questions to decision-making in low-carbon and energy-efficient projects in both new build and retrofit. Our aim in this paper is to make a two-fold contribution: firstly, to use our interviewees as a lens through which to explore decision-making around energy and carbon in offices and schools, gained from our interviewees' extensive professional experience, and, secondly, to contribute to the developing literature on "middle actors" and the MOP in the context of decisions taken on low-carbon and energy-efficient measures in non-domestic buildings in the UK.

The paper is structured as follows. This introduction will focus on three aspects of relevant literature: firstly, a reflection on the importance of a stakeholder perspective in non-domestic buildings; secondly, energy and low-carbon decision-making in schools and offices; and, finally, an introduction to "middle actors" and the Middle-Out Perspective (MOP). Following this, the methodology and approach of this research is described. Themes from our interviews are then presented and discussed in Sections 3 and 4 before final conclusions and implications for policy and future research are reached.

\subsection{The Importance of a Stakeholder Perspective on Energy Use in Non-Domestic Buildings}

Building projects are notable for their sheer number of stakeholders. Purely architectural solutions to energy-efficient or low-carbon investments are, therefore, not sufficient: the people who own and use buildings must also be considered [18]. Yet, surprisingly little research has been done on what drives energy efficiency within businesses and organisational stakeholders [19]. This is consistent with Cole [20], who argued that the motivations, drivers, and the interplay between stakeholders is what is vital to deliver change. Part of this, he emphasises, is understanding how stakeholders see themselves and how they are likely to respond to particular situations. A similar emphasis on the importance of understanding the salience and visibility of energy use to organisational stakeholders 
has also been made in the past by work done for the Department of Energy and Climate Change [3].

Stakeholder relationships give rise to barriers relating to organisational decisionmaking, capital investment, and motivations, which are key to decisions around energy and carbon in non-domestic buildings [21]. In construction, for example, transfers of information and priorities must be made between stakeholders, and there is a propensity for responsibilities for these issues to go astray as they encounter different actors' agendas and working practices [22]. In operation, users of buildings are not only varied but also subject to individual behavioural and collective organisational influences. Janda [23] cites the example of complex interrelationships between thermal comfort, clothing, and work practices in commercial offices. Therefore, it is both the variety and interaction of stakeholders that is important, as group decisions in organisations have their own dynamics around costs, benefits, and strategic goals that are distinct to those of individuals [2].

Stakeholder groups such as owners or users are also heterogeneous. Different sizes and types of building ownership-for example, large organisations compared to small and medium-sized enterprises; public, private, or listed ownership; owner-occupied or tenanted units-have been shown to affect the shape and nature of organisational participation in energy efficiency schemes [2-4]. Different sizes and types of building "usership" are also important. The concerns, capacities, and conditions of occupiers have been shown to affect their energy practices and cultures [23]. Understanding these dynamics is essential as we move from theoretical models to practical actions. We need a better grip on both "achievable potential" (the subset of technologies that are actually installed in practice) and "social potential", which includes both how these technologies are used and other organisational behaviours [2,23].

One solution is to target instruments that work with influential decision-makers and their drivers to produce more energy efficient or lower carbon choices. For instance, marketbased standards, such as the Building Research Establishment's Environmental Assessment Methodology (BREEAM) and the British Council for Offices' (BCO) guidance specifically aimed at commercial offices [5]. However, these have sometimes had unfortunate effects, driving choices that over-specify equipment in the pursuit of compliance and locking-in standardised solutions [24,25]. The National Australian Built Environment Rating System (NABERs) scheme [26] is an inspiration for some in the UK, being taken up and adapted by the Design for Performance initiative [27]. The latter aims to deliver better-performing buildings by working with business imperatives in the commercial office market, such as reputation and marketing, and using the transparency of energy data as a lever to work on the decision priorities of the many businesses involved [9]. Green leases are another instrument that could work with either private-private or public-private relationships within the commercial office sector. This debate around new policy instruments is topical, as the UK government has been consulting on both energy efficiency standards for nondomestic rented properties and performance-based rating schemes [28,29]. Yet we still do not know enough about how decision-making might respond to such incentives in different sub-sectors.

\subsection{Energy and Low-Carbon Decision-Making in Offices and Schools}

Offices and schools provide two contrasting sub-sectors due to their differing occupiers and activities, financing, governance, and regulation, and we will briefly consider first offices and then schools. Of the 13 non-domestic sub-sectors, offices and schools are both commonly studied. In commercial organisations, strategic decision-making does not always adhere to economic rationality [30]. This is also the case for capital investment in building energy efficiency where other "strategic" concerns may dominate the business agenda [31]. Office developers may de-prioritise energy in favour of low-risk solutions that meet standard specifications in the interests of meeting their overall objective of letting their building [25]. Yet there is still potential for stakeholders to participate within a shared 
sustainability narrative about their workplace, if this is fostered between designers, owners, and occupiers [32].

Relationships between commercial stakeholders can be complex. Insights into green leases in the retail sector also show that new instruments must be understood in the context of overlapping interorganisational relationships [33]. Deline [34] also suggests that too much energy research focuses on individuals and not enough on group decisions, such as those in commercial contexts. Boyd and Schweber's study of commercial buildings [22] indicates that, with the accumulated effect of many different stakeholders' decisions, the outcome may be very different from the original design intent. Once built, the relationships between stakeholders may still hamper energy efficiency. Tenanted commercial offices are plagued by the well-known landlord-tenant divide, symptomatic of the complex system of relationships and incentives at work in communities of occupiers and owners and multiple associated stakeholders. Yet amalgamations of energy-efficient or low-carbon solutions across commercial property portfolios have huge potential impact, if they could work across barriers between all these stakeholders [35].

In government-funded schools, there is no less of an issue with stakeholder relationships and incentives, although the players differ. Structures of funding contracts are important, such as those governing the relationships of Private Finance Initiative (PFI) projects in the UK, which was a major driver of capital investment in schools until comparatively recently. A large body of research on these programmes has uncovered significant problems [1]. Although the funding for PFI projects often contained carbon or energy targets, the realisation of these was often compromised by conflicts between stakeholders, such as local government and construction contractors, or by a conscious or unconscious failure to prioritise the targets [36]. Just as in offices, this meant that policies intended to create more sustainable schools were sometimes translated by stakeholders in ways not originally envisaged [37].

Although schools are responsible for a significant proportion of energy use in nondomestic buildings, there have been consistent failings in realising energy saving and delivering new low-carbon schools. This is attributed partly due to a failure of top-down policy to understand how energy is actually used in schools, suggesting a disjunct between school communities and designers [38]. As public buildings, schools are required to prepare Display Energy Certificates (DECs) measuring their operational energy use. Analysis of the data from DECs shows changing patterns of energy use in schools as thermal energy demand reduces, but electricity use rises due to changes in building fabric and teaching practices, with a resultant effect on carbon emissions [39]. Moreover, it would be wrong to think of all schools as similar. Hong et al. [40] show that the variety in pupil numbers, floor area, teaching technology adoption, and age groups all work together to produce different forces acting on energy demand.

It is therefore important to understand how energy "fits with the organisation's wider investment decision-making processes", and what internal and external factors render it sufficiently "salient" to influence decisions and precipitate action [41] (p. 3). Without this, we cannot hope to understand the multiple "barriers" to investment in energy efficient technologies within organisations in the non-domestic sector, including those such as knowledge, financing, and culture [42]. One problem may be that researchers or policymakers frame energy efficiency in different ways to those they seek to understand, as businesses themselves may use different language and concepts to describe why they do, or do not, choose to invest in energy-saving measures [43].

Therefore, there is more to stakeholders than owners and users. In particular, building professionals involved in the development of schools and offices have established working routines and may not respond to regulation or other pushes towards energy efficiency [44]. The concept of reflecting on energy decision-making from the perspective of professional "middle actors" can help unlock this perspective. 


\subsection{Middle Actors and the Middle-Out Perspective}

The Middle-Out Perspective (MOP) intersects with a broader discussion of "intermediaries" in sustainable transitions, who may facilitate action but have less direct agency than actors. Whilst our paper focuses on middle actors, it is interesting to consider how other research has debated the boundaries of actors and their agency. For instance, for Grandclément et al. [45], intermediaries act as "bridges" or "translators" between different actors. They argue that these stakeholders have a significant role to play in energy outcomes in buildings; however, they do not view intermediaries as independent actors with their own agendas. Kivimaa et al.'s review work on the role of "intermediary actors" in sustainable transitions [46] places Janda and Parag's middle actors within a larger landscape of work. Drawing on this landscape, and the work of Van Lente et al. [47], they consider typologies of intermediaries to suggest areas for future research around the definitions of actors that can or cannot exert their own influence toward sustainable change. This includes more empirical evidence on how intermediaries' roles change over time and what mix of intermediary actors work together as "an ecology" to create change.

Janda and Parag's middle actors are those who neither produce nor consume energy, but may nevertheless influence its use, and can generate change from "the middleout" [15,16]. This includes businesses and professional groups, such as architects or engineers, whose activities shape the energy use of the buildings they work on. This Middle-Out Perspective (MOP) emphasises the agency of these groups, differentiating them from passive intermediaries [15,16]. Additionally, middle actors are conceived as existing participants in the system of everyday work and life, whereas intermediary organisations are often created to fill a gap between other actors and enable a specific goal. Middle actors are capable of filling a gap, but it is not necessarily their "job" to do so [16]. Middle actors can exert their influence through enabling/disabling actions, mediation between parties or situations, and aggregation of projects. However, these professionals are driven by their own imperatives, derived from their commercial markets and incentives, and hence may not necessarily use their influence towards low-carbon change [15]. Although our paper is concerned with professionals whose agency is assumed to make them middle actors rather than intermediaries, it is nevertheless interesting to respond to this call for more consideration of the shifting role of those "in the middle" and their surrounding "ecology".

The MOP originally used building professionals to develop the framework, and this links to a further debate about the role of professions and professionalism in the building industry and its influence on low-carbon development [48-50]. For example, Janda et al. [51] applied MOP to housing refurbishment case studies, finding tensions between policy's focus on "technical potential" and commercial building's focus on "market potential", as well as pointing out that traditional cost/benefit analysis of energy savings may be too narrow to capture the full range of commercial concerns. Killip [52] focused on small and medium-sized businesses in the UK construction industry, finding that the overall impact of housing refurbishment may be large in terms of the overall stock, but that individual decision-making is highly atomised across a huge number of professional actors. The entrenched default decisions of these actors, and the industry tendency towards increased specialisation, both drove in a separate direction to the need for greater integration to promote low-carbon buildings. Palm and Reindl's study in multi-unit housing in Sweden also found a similar barrier in professional routines and inertia [53].

Research on the MOP has also considered domestic buildings. Wade et al. [54] consider the neglected role of heating engineers in home heating. Using Janda and Parag, they point out that the engineers are one such key group in between user and technology that have a highly active role in shaping energy efficiency. Frick et al. [55] investigated community groups as middle actors who could be effective messengers for energy-saving initiatives, enhancing individuals' receptiveness to local policy. Similarly, Martiskainen [56] looked at local leaders in community energy projects and found the knowledge, practical skills, and personal confidence of these leaders make them active in making decisions and guiding the 
projects. However, these latter pieces of research focus more on domestic projects, where dynamics may be very different to the non-domestic sector.

Other research has pursued the middle actors' framework in more commercial settings. Goulden and Spence considered the role of facilities managers [57], finding these actors hampered by conflicting, and frequently irreconcilable, demands of commercial priorities, cost, comfort, and sustainability. This illustrates both the potential of middle actors to exert change through their own knowledge, although they are constrained in agency and capacity by the context of their professional environment, and the heterogeneous imperatives of other groups that shape their response. Gluch and Bosch-Sijtsema [58] looked at how environmental experts in the building industry are constrained from bringing about institutional change because of lack of long-term commitment to plans for change in their organisational context and a focus on maintaining current practices. They use Janda and Parag's ideas to suggest that tensions between micro (on the job "real work" by individuals) and macro (institutional change at a larger scale) are worthy of further investigation when considering professionals' role in environmental change. More recently, Simpson et al. [59] found that middle actors-in this case, tradespeople in the building industry-do not have equal ability to influence policymakers upstream and clients downstream. Their downstream influence was greater than their upstream influence.

The literature on MOP indicates there is more to learn about the situated experience of middle actors and about what constitutes "the middle". Our research uses the MOP to investigate another set of expert middle actors, as described in the next section.

\section{Materials and Methods}

The data for this research was gathered from semi-structured interviews, conducted as a pilot project in 2019-2020 on the non-domestic buildings market in the UK. This pilot was part of a larger European-funded research project of "Building Market Briefs" [17], that focused on the domestic buildings market in the UK and drivers and barriers for energy and carbon decision-making within it. The scope of the interviews was designed to explore how some of the methods used in the domestic "Building Market Briefs" could fit the diversity of the non-domestic sector. It was also adapted for use with an elite and specialised approach [60], suited to professional middle actors.

We focused on experts who worked with stakeholders in two non-domestic subsectors-commercial offices and publicly-funded schools-for several reasons. Nondomestic buildings are diverse, and, therefore, focusing on two sub-sectors aimed to limit some variability of form and function. Additionally, we wanted to explore potential differences between private and public ownership and decision-making. We felt that it was important to pinpoint two sub-sectors, rather than a split between private and public buildings, as the stakeholders, budgets, energy use profiles, and technologies can vary within these broad groups quite significantly. Pragmatically, our existing research networks allowed us to access relevant experts more easily and to have informed conversations, which can be critical for establishing credibility with experienced professionals [61]. The interviewees were selected for their expertise, which we considered as derived from long and aggregated experience in energy and buildings strategy and practice.

An interview method was chosen because survey methods cannot be used where the operational dynamics are not well-researched enough to assume that the constructs behind survey questions are valid and shared between the researcher and the respondent. This was felt more appropriate to exploring the complex dynamics of decision-making. The research team also felt that an interview approach tailored to elite and specialised interviewing made best use of limited resources for time-constrained, exploratory research by granting fast access to new or unknown fields, and was a quick way to obtain both aggregated knowledge and specific information [62]. It is important to note that the interviews were intended as an exploratory study into low-carbon and energy-efficient decision-making, and that the sampling approach and methods reflect this. 


\subsection{Sampling Approach}

As this was an exploratory study, a stratified sample approach was not applied. Instead, we identified a small number of elite intermediary groups that specialise in understanding and aggregating the views of stakeholder organisations, for example, property industry bodies, or sustainability advisors involved in many projects. Interviewees were divided roughly evenly between the energy demand side (e.g., representing building owners) and supply side (e.g., providing energy and carbon management services). This partitioning was used in the previous domestic sector "Building Market Briefs" [17] so we wanted to reflect this approach in the non-domestic pilot study. There were also organisations who could provide useful strategic overviews of the market, touching on both supply and demand (e.g., some sector specialist groups). All of them can be considered "middle actors" in the terms of Janda and Parag's perspective, although some might also be considered "intermediaries" by Kivimaa's definitions.

We completed 15 interviews. As much as possible, we chose experts who have an overview of the field and who worked with many other stakeholders. For instance, a property membership organisation can provide a market overview that would have been time-consuming, more difficult, or even impossible to gain by talking to their members directly. Moreover, elite interviewees are often highly networked [62], so one interview can easily lead to others by recommendations in a snowball strategy. They are often willing to cooperate and exchange information, and the problem of influencing them by asking leading questions is less likely to occur. Compared to a survey method or non-expert interviews, an elite expert interview method improves construct validity.

Table 1 shows the completed interviews. Not all of our interviewees consented to be identified, so we have presented all the findings anonymously, and the table shows the anonymised identifiers used in the findings. To protect anonymity, we have used different identifiers in this paper from the Building Market Brief.

Table 1. Completed interviews and anonymised identifiers used in the analysis.

\begin{tabular}{|c|c|c|c|}
\hline Sector & $\begin{array}{l}\text { Orientation and Number } \\
\text { of Interview Respondents }\end{array}$ & Respondent Organisation & Identifier \\
\hline \multirow{3}{*}{ Offices } & Demand (3) & Real estate and sustainable property bodies & ODa, ODb, ODc \\
\hline & Supply (5) & Buildings and sustainability advisory consultancies & OSa, OSb, OSc, OSd, OSe \\
\hline & Other (1) & Facilities management expert & $\mathrm{OO}$ \\
\hline \multirow{3}{*}{ Schools } & Demand (3) & Architects and sustainability advisors & $\mathrm{SDa}, \mathrm{SDb}$ \\
\hline & Supply (2) & $\begin{array}{l}\text { Energy services provider, and energy } \\
\text { performance contractor }\end{array}$ & $\mathrm{SSa}, \mathrm{SSb}, \mathrm{SSc}$ \\
\hline & Other (1) & Energy efficiency consultant & SO \\
\hline
\end{tabular}

\subsection{Interview Themes and Analysis}

The interviews were semi-structured to balance our focus on energy and low carbon decision-making, whilst also allowing the interviewee to act as a "conduit through which the participant tells their story" [63] (p. 76). The interview guide concentrated on a few open-ended questions for discussion with each actor, shown in Table 2 below. The interviewers focused questions on the office or school sub-sectors and followed up specifics from each prompt as the discussion developed. Interviews were conducted face-to-face where possible and remotely when not (for example, where travel was not feasible). The interviews were recorded and transcribed to facilitate precision. Two of the authors conducted the interviews, and each additionally produced a short note of interview reflections following each encounter. These reflections were used alongside the full transcripts to facilitate discussions of potential themes amongst the research team.

We analysed interview data using the well-established approach of thematic analysis [64], incorporating a hybrid inductive and deductive coding approach. The latter allowed us to define some codes a priori from our MOP framing, whilst also allowing 
others to emerge from the interview data [65], aiming to balance our conceptual interests with sensitivity to the data [66]. Analysis was conducted specifically for this paper in NVivo. Following discussions between the team members, a code book was established for NVivo. The top-level codes drew specifically on the MOP, aiming to explore where middle actors were enabling/disabling, mediating, and aggregating energy efficiency and low-carbon decision-making or indeed where their agency and capacity were failing in these areas. In addition, top-level codes were created to capture other forms of influence on decisions in schools and offices beyond the interviewees themselves and to capture evolutionary elements of the MOP (such as ecologies of middle actors and change over time). Finally, "memos" were used in NVivo for each code, to reflect on the coding and develop themes across the data. These themes have been used to structure the findings presented in Section 3. Together, the coding and analysis were intended to pursue the dual research aim of capturing middle actors' experiences of decision-making and to reflect on the dimensions of the MOP itself. This process is summarised in Figure 1 below.

Table 2. Interview questions.

\begin{tabular}{cl}
\hline No. & \multicolumn{1}{c}{ Question } \\
\hline 1 & $\begin{array}{l}\text { Please describe your organisation and how your role fits within the context of energy and carbon saving within } \\
\text { non-domestic buildings. }\end{array}$ \\
\hline 2 & $\begin{array}{l}\text { What is 'your' experience of organisations' interest in investing in/or adopting energy efficiency, carbon } \\
\text { reduction and energy performance in non-domestic buildings? }\end{array}$ \\
\hline 3 & $\begin{array}{l}\text { How would you characterise the decision-making process that is undertaken when deciding on energy } \\
\text { efficiency/low carbon investment? }\end{array}$ \\
\hline 5 & $\begin{array}{l}\text { How would you describe organisations' levels of commitment to investment in energy efficient/low carbon } \\
\text { strategies and technologies? What influences those choices/level of commitment? }\end{array}$ \\
\hline 6 & $\begin{array}{l}\text { How would you characterise the last } 5 \text { years in terms of investment in energy efficiency/low carbon strategies } \\
\text { and technologies, and what types of actions have you seen being adopted? }\end{array}$ \\
\hline 7 & $\begin{array}{l}\text { What (if any) strategies and technologies have you seen which could have been adopted, but have been rejected? } \\
\text { And has there been any change in the last 5 years? }\end{array}$ \\
\hline
\end{tabular}

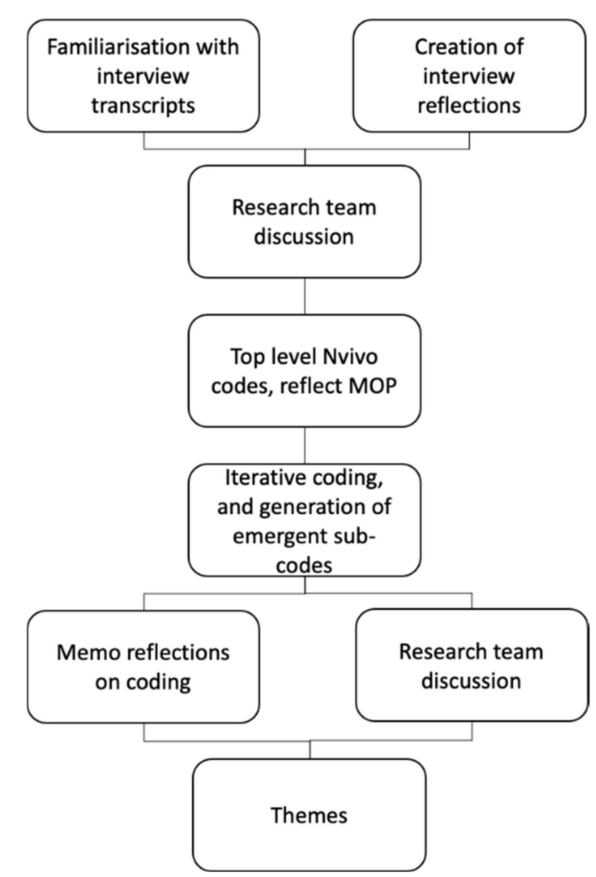

Figure 1. Summary schematic of analysis process. 


\subsection{Limitations}

An obvious limitation is the small sample size, partly occasioned by the exploratory nature of the study, and the deliberate selection of experts in two sub-sectors, making a smaller pool inevitable with the resources and time available. Although other studies in this area of research have had successful results with similar interview sample sizes $[49,59,67,68]$, future research would benefit from investigating these initial exploratory findings amongst a wider selection of interviewees. Additionally, in some cases, respondent organisations are "pro-environmental", which may introduce a positive bias towards the adoption of low-carbon strategies and technologies. We have attempted to counter this bias by asking all respondents to also discuss measures that were rejected and why. Interviewees were selected according to their role as either "supplying" or "demanding" energy efficiency to reflect the characterisation used in the original research project. However, we found that these categories were not so clear-cut. For example, "demand" respondents often talked about their experience with energy-efficiency suppliers, and vice versa. We have coded the interviews according to the professional role that interviewees serve in the market, rather than on the content contained in their responses.

As noted in the introduction to this paper, the non-domestic sector is not a unified whole, and is, therefore, quite difficult to characterise, and this is reflected in our methodology. For instance, in the office sector, there are distinct differences between market leaders and middle-market properties (the implications of which are discussed later in the findings). In addition, we initially selected offices and schools to represent archetypes of privately-held and publicly-funded properties because we wanted to explore middle actors' perspectives on, and roles in, different decision-making processes within contrasting sub-sectors. However, there is variability even within these sectors, as there are many publicly-held office properties which we did not specifically address or explore in this study, and there are schools (e.g., academies) that operate much more like private entities, even though they receive government funding. These could be usefully explored in future research.

\section{Results}

\subsection{Finding and Influencing Decision-Makers}

In order to maximise their capacity to influence change, identifying the decisionmaking hierarchy can be the first line of approach for middle actors. In schools, there can be multiple decision-makers who carry authority, all of whom must be brought on board, and each of whom has a different stake in the decision. For maintained schools, the local authority can be a key stakeholder, because it holds the budget for larger interventions and a portfolio of local schools. Therefore, access to this decision-maker facilitates middle actors' ability to aggregate influence across the whole body of the local authority estate. Below this, there are also a multitude of decision-makers in the individual schools themselves:

"You've got your Head Teacher, your Business Manager, your Caretaker, and the school Governors all have to sign up to it, and that's the problem with schools. There are so many people who have an input and if you don't cross all those off it never happens"-SSc.

In commercial offices, access is also key, and here it can be important to engage other middle actors who have access to ultimate corporate-budget holders:

"There are lots of gatekeepers, who may or may not present options to the decision-maker"-SO.

In-house sustainability teams in commercial projects are frequent first points of contact, and provide a sympathetic ear, but do not necessarily hold control over expenditure. Instead, our middle actors supported sustainability teams in taking energy issues to those that do manage budgets. Another group of stakeholders who may act as conduits are facilities contractors acting as the "intelligent client function" (OSc), meaning that they present the business case back to their employers for approval. Middle acting gatekeepers 
can be protective of their professional roles. For instance, one architect described this barrier between his organisation and the client:

"Our contract is with the contractor not the client ... So, for us to go round the side and talk to the client is a bit no no. So, there's a kind of professionalism we have to respect..." $-\mathrm{SDb}$.

Timing is also critical to middle actors' ability to enable decisions. Not being "brought in early enough" (OSc) is a frequently mentioned problem in our interviews: as one actor jokes, "it's always, 'Not yet, not yet, not yet. Whoops, too late"” (SDa). Clients may push too hard on project timetables, losing the time to focus on energy, and this can knock on into advisors' ability to think creatively, leading them instead to implement standard solutions that they know they can get done on time (OO).

Further difficulties emerge when budgets are split between operating and capital expenditure, creating a split incentive. The example of the landlord-tenant divide in offices is well known, but these divisions affect both schools and offices:

"It seems crazy given that it's the same organisation providing those pots, but people are very protective over, 'This is my capital budget and I'm not going to spend $£ 10$ more even if it saves $£ 1000$ down the line because it's coming out of my budget, my pot'"-SDa.

School project proposals are often assessed on capital cost by those who are "not the team that will run the building at the end" (SDb). Furthermore, education and planning decisions are separated by departmental boundaries. In offices, another interviewee described a "game" of trying to pass through as much expenditure as possible into the service charge and, therefore, someone else's "pot". These different budgets may also be subject to differing approval processes. As OSc explains, a division can be made between "minor" and "major" work based on the capital value, with the former subject to a less onerous process and, therefore, easier to implement but with a smaller overall impact on the building's performance. Middle actors in the school sector observe a similar split, with small scale works being carried out without formal approval (SO). Finally, the rotation of contracts in offices is a further challenge. This phenomenon includes office tenants with little long-term interest in a building they commit to occupy for only a few years and facilities managers where accumulated skills may be lost:

"One of the issues there is that if you sell the building on, you usually got rid of the FM (facilities management) team or the property management team, and then you had to start over again"-OO.

From this, it is evident that internal management structures are critical to an understanding of energy and carbon decision-making in both schools and offices, but they do offer a possibility of magnifying influence, if leveraged effectively. If powerful decisionmakers can be won over, a portfolio of buildings can be accessed on an aggregated basis. This principle is relevant to both schools and offices, although the decision-makers vary. The frustration of some middle actors is that government policy persists in thinking that "non-domestic buildings are big houses" by looking "at buildings and not at portfolios" and, therefore, choosing an ineffectual point of influence:

"The problem is that normally the policymaker wants to lasso the physical unit, and, no, sorry, if you want to get the market to change, you have to lasso the management unit"-ODc.

Yet as OSb observes, some businesses themselves can also focus myopically on individual asset performance: "the closer you get to the asset the shorter horizon you see". The dynamics of this will, however, vary, as our interviewees noted the difference in focus between owner-occupiers and corporate landlords. Once again, this emphasises the importance of middle actors' understanding of ownership and management variables and targeting intervention at the appropriate "management" level. 
Successful projects are also potential magnifiers for middle actors. As SSc relates, projects that do deliver energy savings are "gold dust" for the schools he works on, as once a few successful projects have been completed, the schools themselves become powerful advocates for change, and word-of-mouth recognition from influential stakeholders, such as school business managers, can provide much more impetus than the middle actor. Projects deemed unsuccessful can also be magnified but have the opposite effect by acting as brakes on decision-making. The Department for Education, for instance, was held to be unwilling to commit funding to new technologies they perceive as risky, and schools themselves are also wary.

In the private sector, evidence that energy-efficient or low-carbon buildings are commercially worthwhile could have a similar effect. However, our interviewees felt that office stakeholders remained unconvinced of this and indeed expressed cynicism themselves (evidence on green rental premiums was deemed "flaky" by ODc). For the financial players who invest in buildings, "investment grade" criteria that would allow them to reliably differentiate between a green and non-green building would aid their commitment as much as any evidence on the relative performance of green buildings. As a result, developers may choose not to pursue adventurous low-carbon features which might take up valuable floor space $(\mathrm{OO})$ or fail to attract tenants when considering either new build or retrofit. Several of our middle actors suggested that building labelling schemes similar to the Australian NABERs model could catalyse the green building market, but upstream influence to lobby for this scheme was not within the agency of most of our interviewees. This potentially powerful influence on decision-making is not currently at work.

\subsection{Changes in the Debate}

The UK's commitment to Net Zero and the rising interest of the investment community in Environmental, Social and Governance (ESG) performance featured in our interviews. Whilst our middle-actor interviewees had long experience of the difficulties in persuading decision-makers into low-carbon options, they had perceived a shift in the landscape recently:

"Certainly, in the last 12 months there has been a shift in the discussion of what is required in terms of the conversation around net zero carbon. And I think it's very much changing from oh we need to continually make improvements in energy efficiency ... of a couple of percent a year, to fundamentally you need to drastically change the way in which our buildings are consuming energy"-ODa.

In the commercial offices, investor pressure is a major emerging factor:

"It's high up-if not top of the agenda-in terms of due diligence in investment decisions and development decisions"- $-\mathrm{ODb}$.

As another interviewee explains, this is the result of the interplay of several factors. A tightening of property-specific regulations, in particular compliance with the MEES restrictions preventing the letting of energy-inefficient property, has mitigated some of the inertia noted above. However, non-building specific issues were also important, in particular, national legislation around Net Zero and corporate sustainability reporting requirements, both mandatory and voluntary. These had collectively focused attention on the emissions of property portfolios, with the danger of "stranded assets" now emerging as a concern around future legislation:

"We've seen Science-Based Targets and Zero commitments, long-term strategic energy and carbon reduction plans being developed ... we're starting to see the business case for energy efficiency being made on grounds other than just pure energy saving"-OSa.

"If you're looking at a given building or a given portfolio of buildings you want those to be fit for purpose in the future ... what people want to avoid is having assets effectively stranded in the future where a high standard of energy 
efficiency is required and there might be quite high costs for increasing to the relevant level"-ODb.

The experience of several of our middle actors is that a corporate commitment can override the usual payback hurdles and alter investment decisions:

“The payback becomes irrelevant. If they want to achieve it, they need to do it"-OSe.

Other middle actors explain that this may be more relevant for businesses with consumer-facing brands, whose office buildings need to make a visible "sustainability statement" to visitors and staff. This chimes with middle actors noting an increasing concern amongst both the general public and companies' own employees, again putting pressure on the organisations who own or manage buildings to be seen to be taking action on climate change. As one actor observes, "we seem to be just past some sort of tipping point in terms of public concern"-OSe.

In schools, carbon targets and a declaration of climate emergency in the public sector has placed a similar emphasis on reducing the emissions of local authorities' estate footprints, of which schools form a significant proportion:

"There's so much of it going on in the public sector largely driven by the declaration of climate emergency ... It's been an absolute godsend for us, it's been great. It's really generated a lot of growth"-SSc.

Schools are responsible for paying their energy bills but suffer from a lack of time and resource to monitor costs and usage data. Local authorities' impetus to take an interest in energy usage, and apply pressure to reduce it, has provided a new source of leverage. This means that, once again, the "management unit" is key to change, as, without this centralising pressure, energy may be of less concern to the individual schools themselves, who are deemed by our middle actors to be less affected by any shift in low-carbon debates.

Whilst this shift in the public sustainability debate was often mentioned as the most significant recent change, development of low carbon technologies and corresponding falls in their prices has also greatly enabled middle actors' ability to present a convincing business case for energy efficiency. Technological development has also reduced the perceived risks (advances in building controls were cited as one example). Given that the majority of our interviewees emphasised the short pay back periods, frequently of as little as 2-3 years, demanded by many budget holders, particularly in corporate office clients, this cost reduction is important. It is, however, not always sufficient. Several middle actors noted that clients sometimes deferred technology upgrades hoping for further cost reductions or preferred to hold out for further government financial incentives. A further factor was the decarbonisation of the UK electricity grid, which increases the carbon saving of electricity-focused projects, such as local heat networks.

However, the shift is not uniform in either sub-sector. In offices, it was developments outside prime locations that were considered further behind in low carbon prioritisation, with the majority of interest arising in the "blue chip" customers of middle actors. One interviewee noted that it was "quite striking" that "the top tier" of the office market was much more aware than regional or lower tier counterparts. Lack of resource affects these lower tiers:

“The problem with the call centre in Rotherham is the person who's making the decision about energy efficiency is doing 101 other things. And, you know, he or she just doesn't have the brain space to think about it" - SO.

Another interviewee used the example of high salary costs for "blue chip" companies, such as London banks, for whom rent is a lower proportion of costs, rendering the incremental cost of low-carbon buildings less material than for smaller businesses.

In schools, the increasing numbers of academy schools can affect local authorities' willingness to act, if they cannot be certain which schools will remain part of their managed estates in the long term. Additionally, funding cuts were held to be substantially reducing 
investment across the public sector estate, including schools, where OSc noted that" from a maintenance and estates perspective, the money's been taken off the table". Our middle actors, therefore, found that energy-saving technologies were valued in schools when they were cheaper upfront, promised to reduce maintenance costs (for instance, LED lighting), or when the capital expenditure was supported by additional funds from other grant schemes. However, this again was not uniform, for example, with different funding being available across the devolved administrations.

Whilst there is confidence amongst some interviewees that this shift in the debate could be a new beginning- “I think to one degree it will be a case of where the leaders go others will follow" (OSb) - other interviewees also point out that increasing awareness and ambitious target setting is all very well but may not necessarily translate into action on the ground in either public or private sectors. Some interviewees mentioned the need to update standards, and others emphasised that if other middle actors, such as construction companies or facilities managers, are not held formally responsible for energy performance, then they lack incentive to take meaningful action. Some middle actors, therefore, argued strongly for changes to contracts, as without this, energy efficiency and low carbon remain just "warm thoughts" rather than action (ODc).

\subsection{Finding the Pressure Points for Sustainability}

As discussed in the previous two sections, motivations and responsibilities for carbon reduction and energy use may vary considerably between and within sub-sectors and stakeholders. Many of our middle actors viewed their role as educational "advocates", making energy and carbon issues visible to their clients, providing detail on recent technological and regulatory developments, and being a "champion" who raises energy issues onto decision-makers' agendas. This role was described in similar terms by those working in both office and school sectors. A sensitivity to these motivations and responsibilities is, therefore, important if middle actors are to identify the pressure points to allow them to "advocate" most effectively.

This role can involve identifying technical energy-saving options. For resourceconstrained schools, it can mean compiling basic energy usage data when facilities managers (if indeed they are present at all) have little time available to do this. For offices, meter data can also be hard to access and requires "visibility" to incorporate it into reporting channels. However, mediation can also encompass a more "systemic" review of building performance factors, with the aim to get building stakeholders to pay "more attention to what your building is doing" (ODc), as frequently neither schools nor offices understand the energy use of their buildings. This should ultimately embed knowledge in the organisations, giving them capacity to make their own low carbon decisions in the future.

Middle actors sometimes felt, however, that engaging directly with the low carbon debate-no matter how increasingly topical it has become-was not always the best approach. For both offices and schools, translation into financial metrics can help shift decisions. In budget-constrained schools, this might be highlighting cost savings. In offices, the fit with key performance indicators, such as rental values and net lettable area, can be critical. The pressure points also shift over time. For schools, this might mean current curricula, teaching styles, and student wellbeing issues (air quality is an example of a current issue on schools' agendas); for offices, middle actors require the market outlook for rents and capital values and consider how these frame investments in energy efficiency.

Working energy around key organisational functions is vital. In schools, minimising disruption to staff and students is critical because:

"Rightly so, schools are worried about education first, it's their core business"-SO.

Thus, whilst they might be drawn to potential cost savings, worries about being disrupted through building work, functionality being impeded, or indeed valuable staff time being taken up are all concerns when staff are commonly over-stretched. As a result, making the energy more visible is not always the solution schools want. Indeed, one 
respondent suggested that passive design worked well in schools exactly because it was unobtrusive:

"You don't need an ethos change to operate it ... the teachers don't have to deal with it ... it's almost 'guerilla greening' buildings, it's about how do you do it without impacting the average school day" - SDb.

In offices, there can be a similar concern with avoiding disruption to tenants and getting core business done, but there is more of a concern noted around the benefits of the look and feel of a building and concern over staff wellbeing. These concerns have previously worked against substantive engagement with energy efficiency. As SSa observes:

"So, 90 something percent of an organisation's operating costs are staff-related, so anything that impacts on staff's performance is a much bigger part of the balance sheet than energy".

Such concerns could, however, increasingly complement building energy and carbon emissions. Given the new interest in carbon's effects on long-term asset values, sustainability can meld with a wider vision of "real long-term investment in place" by investors $(\mathrm{ODb})$. In this perspective, energy efficiency, some of our interviewees suggested, could join up with social value in creating communities that are healthy and environmentally responsible places to live and work. This could fit into the public sector agenda as well:

"Energy efficiency in itself just doesn't seem to excite people because energy is cheap basically in the grand scheme of things, but ... now they've sort of overlapped with social value, and social impact again is another area where you have the comfort story. And creating healthy operational buildings is another touchpoint I think where energy efficiency connects to clients and building users in a way that maybe could further its cause" -SDa.

Finding pressure points that reveal energy in ways that stakeholders respond to, and in ways that complement core organisational priorities, is, therefore, important. Where energy fits well to organisational pressure points, decision-making towards energy-efficiency and low-carbon issues will be catalysed; where the fit is poor, it will not. Middle actors flexibility and sensitivity to identifying these pressure points emerges from our data as part of their professional expertise.

\section{Discussion}

A key theme emerging from our pilot findings was an expansion of the "middle". Previous research considering middle actors has often focused on buildings professionals [49,50,52,54,57], environmental experts [58], and even local communities [55] to consider those with agency and capacity to create change. Our interviewees had perceived a recent shift in the low-carbon agenda, leading them to encounter other sorts of middle actors beyond building, energy, and sustainability professionals. This included institutional investors, banks, and voluntary sustainability schemes, for offices in particular, focused at corporate rather than building level (such as the Science Based Targets initiative). Whilst our interviewees might not meet these actors directly, their agency was nevertheless affected by them, such as when a corporate-level Net Zero goal overrides payback thresholds. This perceived shift also reveals the dynamic "ecology" of expertise [69] and middle actors in sustainability, raised as a continuing gap in current research [46], and encourages us to consider how stakeholder interactions in the non-domestic building arena might alter in response to increasing emphasis on corporate ESG and Net Zero. Changes emerging from the current pandemic are likely to shake up the kaleidoscope of this ecology further.

The interviews also revealed middle actors' sensitivity to pressure points in schools and offices. They used this situated awareness to maximise their agency as low-carbon "advocates". This provides a very interesting counterpoint to work in domestic buildings, which has previously tried to delineate actors who are "championing" and "nonchampioning" in sustainable buildings [67]. However, this situated advocacy could risk 
yoking recommendations too tightly to stakeholder concerns. For instance, one middle actor described how tailoring technology choices to the financial thresholds of schools and grant funders transformed stakeholder acceptance but drastically limited the options implemented. Other ESG issues, such as social value or occupant wellbeing, can also be harnessed to facilitate interest in low carbon but can risk middle actors being side-tracked by topical but transient issues. One interviewee observed that their corporate office client base had already moved on from carbon to the new "buzz" themes of circular economy and embodied carbon in building materials. The distinction between astute appropriation of client concerns and being subsumed by them makes consideration of these middle actors agency more complex.

A further theme to emerge from those we interviewed was the magnifying effects of these middle actors' capacity to influence change by engaging key decision-making units, such as local authorities for schools or commercial office portfolios. The middle out perspective already indicates the ability of actors to aggregate experience across multiple projects and for them to influence "sideways" by increasing other actors' agency or capacity $[15,16]$ Our findings suggest a further nuance that sustainability professionals could act as catalysts for other middle actors to themselves aggregate projects. For policymakers and others in search of points of leverage to promote greater take up of low-carbon buildings, this is potentially interesting. Aiming to "lasso"-in the words of one interviewee-stakeholders with the ability to magnify influence would expand our conception of the potential role of middle actors in sustainability advocacy. Table 3 (below) represents the links between these experiences of middle actors, the examples noted in our data, and the implications for the MOP.

We set out to explore what we believed might be two contrasting non-domestic subsectors of schools and offices. We found contrasts between these in terms of who and what the middle actors engaged with, for example, in budgets and decision-makers. We found similarities in the strategies that the middle actors used to engage, in which they used their situated awareness of organisational context. Indeed, the importance of organisational context for both pressure points and decision-making units emerges strongly from our data, as noted in existing work on non-domestic buildings that has equally sought to explore organisational "engagement" with energy in buildings [70].

Our exploratory findings question whether policy should aim for individual buildings. Whilst there are obvious differences in form and function between schools and offices, our findings also showed important differences in their management structures as well, partly due to sectoral differences but also dependent on the individual organisational context. Advocates for a NABERS-style office rating scheme that separates energy use between base buildings and their tenants derive from this managerial perspective [27]. Our findings suggest possible wider interactions with other ESG concerns. For offices, this links to corporate reporting and company funding, for schools, to public sector carbon targets. Disconnects between these high-level targets and on-the-ground action may be as relevant in a Net Zero UK as the familiar debate around the building "performance gap". The stakeholders, as described by our interviewees, are not making decisions about low-carbon buildings; they are making decisions about their budgets, working environment, and educational (schools) or corporate (offices) priorities. Policy that situated buildings within this organisational context could catalyse both commitments and action. 
Table 3. Results and Discussion, showing links between middle actors' experiences, supported by the interview data, and the implications for the Middle-Out Perspective (MOP).

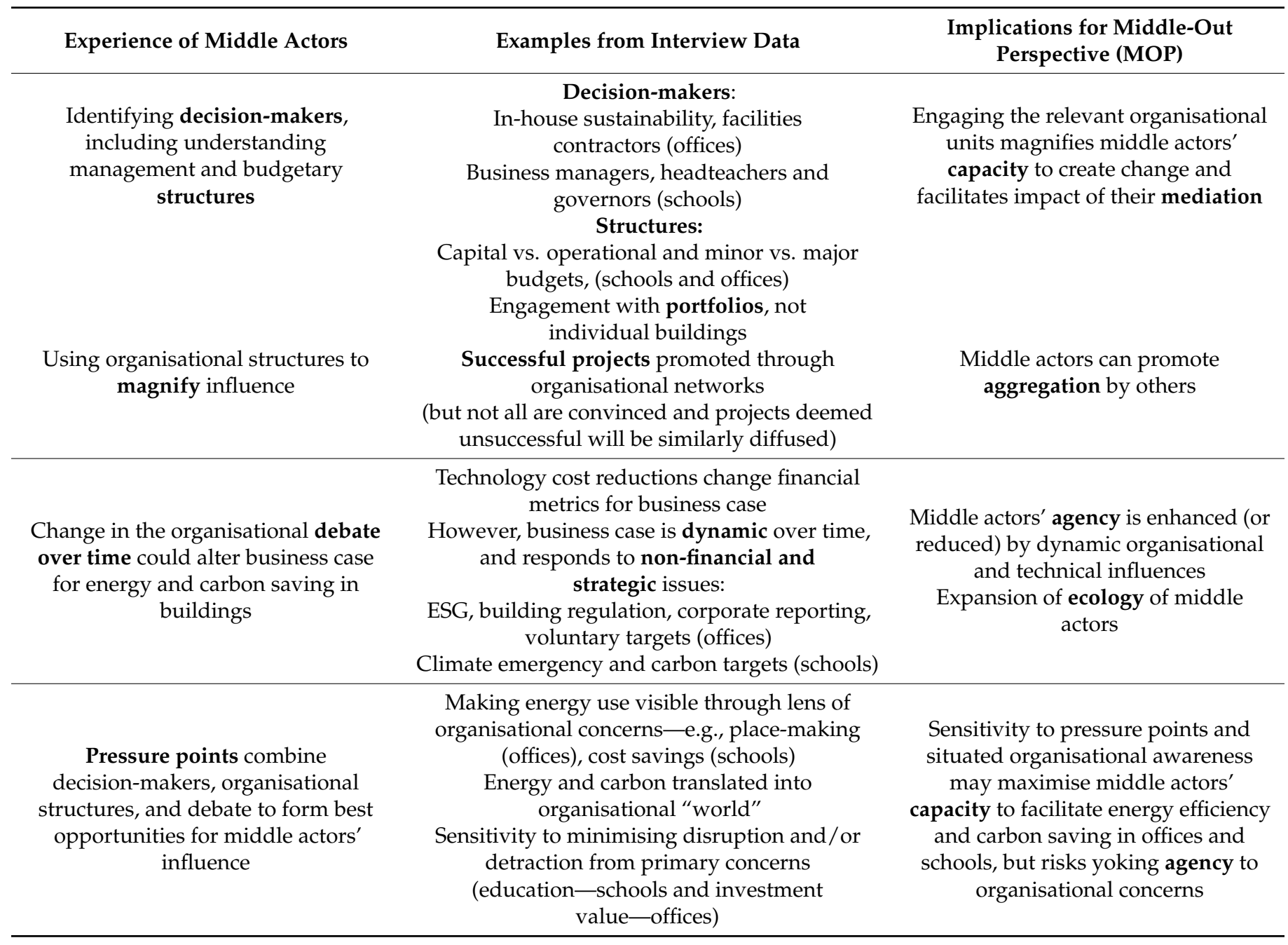

Many challenges remain. Many of our middle actors had fought what felt like an uphill battle for years and remained cynical. Research has also frequently emphasised the apparently intractable structural and incentive barriers causing building stakeholders to work against each other $[9,20,41,43]$, as noted at the outset of this paper, and indeed our findings also find evidence of these. Yet, successful building rating schemes in the US and Singapore as well as Australia have overcome some of these difficulties [27]. Mallaburn et al. [68] observe that the secret can be to increase the "salience" of building energy to organisational decision-makers. Our findings further indicate that identifying the levers that apply to decision-makers and the issues and advisors of salience to them may go far beyond the boundaries of any physical building. In Figures 2 and 3 below, we indicate how expanding policy beyond specific building fabric and technical features could capitalise on a greater scale of intervention, and engage with a wider set of organisational issues and actors. This corresponds with research into the need for an integrated package of building policies [71] and climate policymaking that also accounts for multiple objectives and actors to create change in sectors such as buildings [72]. It also speaks to the debate around frequently problematic single indicators for specific buildings [73,74]. Systemic policy intervention is needed to muster change at scale for Net Zero in the UK. Recognising that change in buildings comes not only from buildings policies creates an opportunity to engage with this policymaking need. 


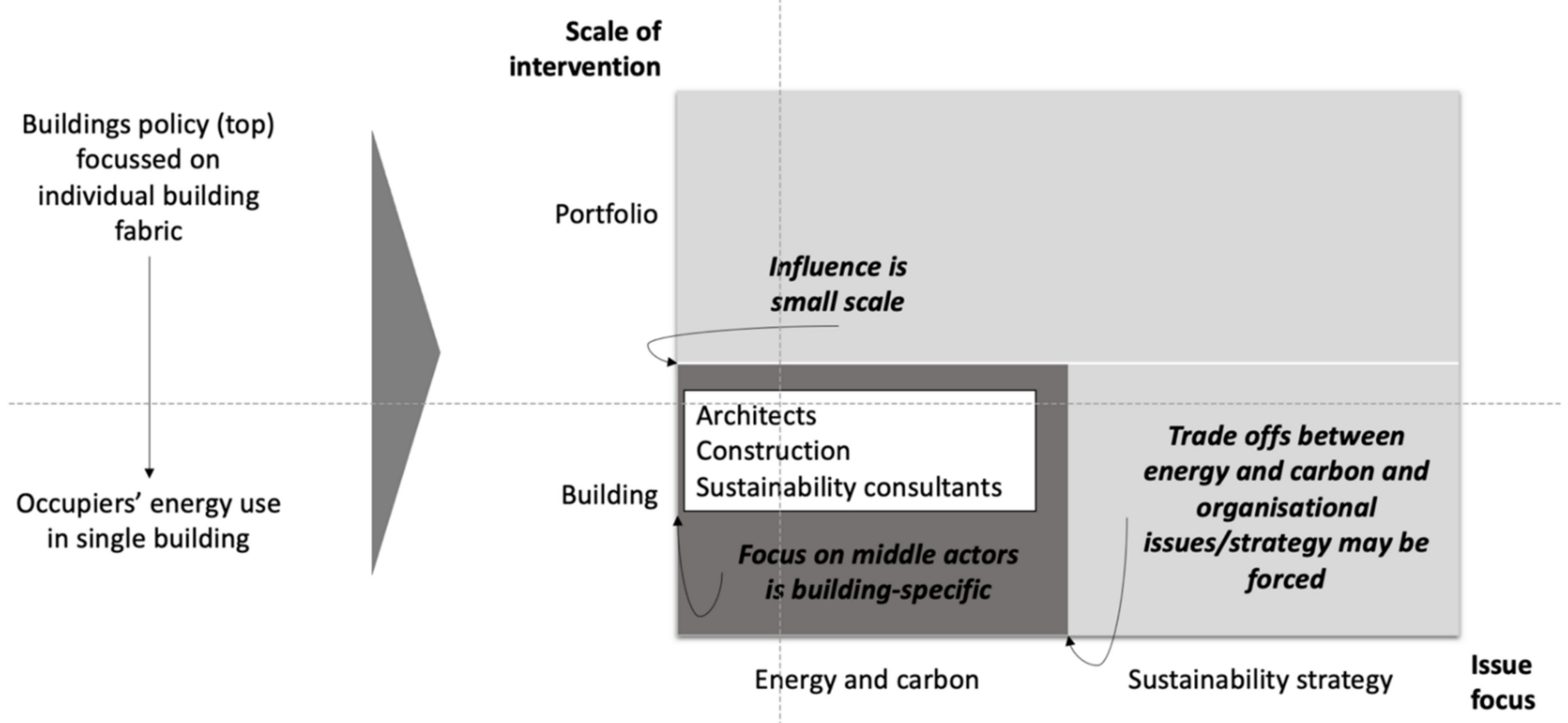

Figure 2. Policy focused on individual building and its fabric.

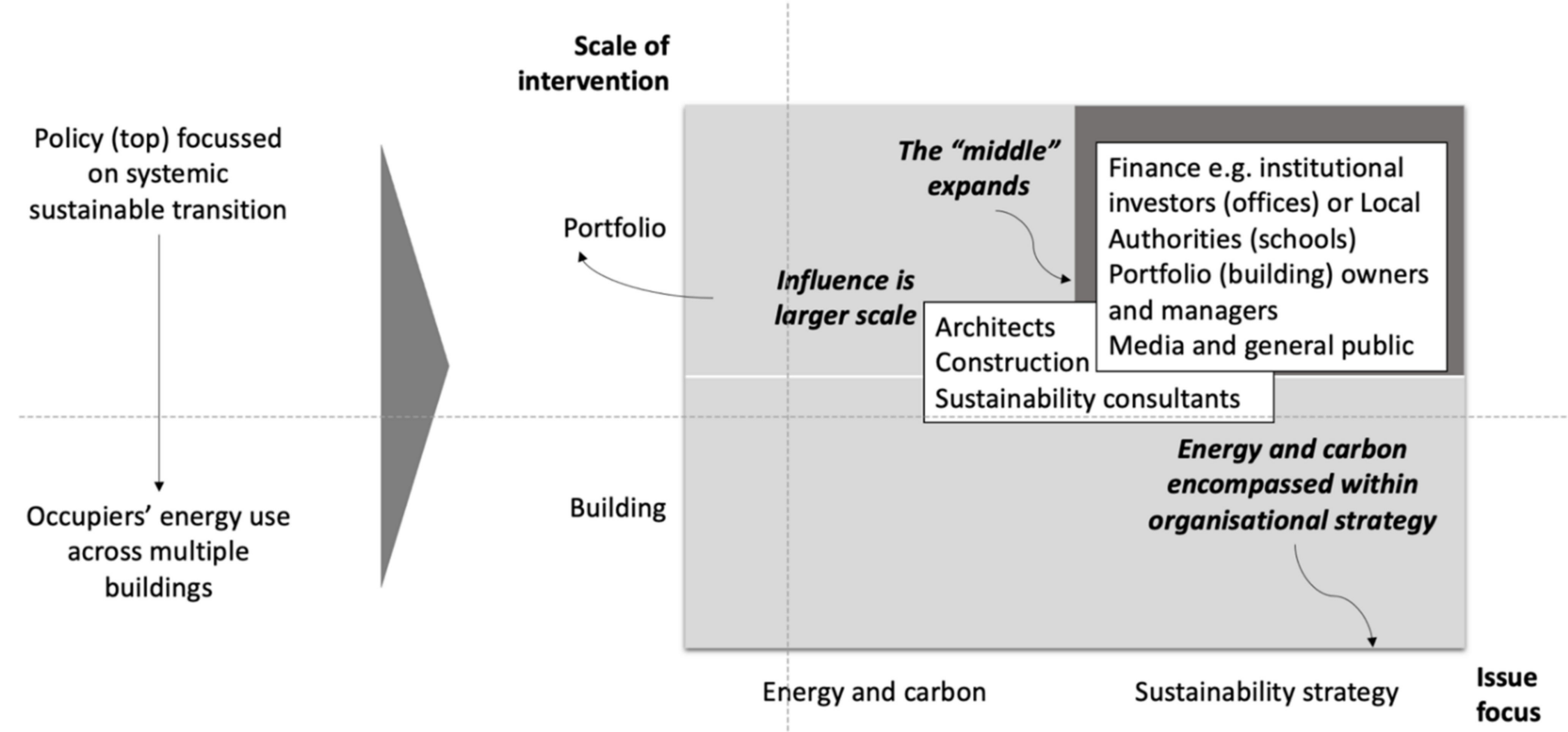

Figure 3. Policy focused on buildings as part of systemic sustainable transition.

\section{Conclusions}

The aims of this pilot study were to engage with experienced middle actors in lowcarbon buildings in the UK, in order, firstly, to reveal expert knowledge about decisionmaking into energy-efficient and low-carbon buildings, and, secondly to allow us to reflect on the role of these middle actors and the nature of the "middle". We chose two contrasting non-domestic sub-sectors of offices and schools and discussed both new build and retrofit opportunities. Our data collection comprised in-depth interviews with a range of experienced building sustainability professionals.

The exploratory findings of our interviews revealed some commonalities in decisionmaking despite the hugely different activities, budgets, and stakeholders of offices and schools, for instance, the problematic division between capital and operating budgets and 
concerns about perceived disruption of energy-efficient refits to core activities. Conversely, we also found divisions within the two sub-sectors, such as varying motivations between local authorities and school leadership or between "blue chip" London office tenants and their provincial equivalents. Overall, this could point to the importance of appreciating individual organisational context for decisions rather than individual school and office buildings.

The UK has set ambitious targets to decarbonise. Non-domestic buildings will need to play a vital role in the achievement of these, but UK policy has long struggled to gain traction. Our findings confirmed many problems indicative of long-standing structural issues standing in the way of low-carbon buildings that are familiar from previous research $[3,20,42]$. However, our interviewees suggested possible pressure points that could facilitate future decision-making towards low-carbon options and even create possibilities for change at scale if aggregated. These points included issues, which might be considered tangentially relevant to buildings but were of great relevance to the decision-making of middle actors' clients. This includes concern around climate change in the general public, recent trends and regulations in corporate reporting and the investment community, and investment in social value. This had also broadened the scope of middle-acting professionals (notably in the increased engagement of commercial investors and public institutions). It had also given increased agency to middle actors with long interests in sustainability to suggest low-carbon strategies or technologies but not necessarily the capacity to translate them into action.

Overall, this could suggest that incentivising low-carbon buildings is not exclusively about policies for buildings. Instead, a policy mix relating to and surrounding low-carbon buildings could work in reinforcing ways to align the many stakeholders and dimensions of corporate sustainability management within which buildings are situated. For example, new policies arising from government's evolving Net Zero strategy could incorporate buildings as part of a systemic shift to lower emissions in the UK. Existing policies aimed at the organisational unit, such as the Energy Savings Opportunity Scheme and mandatory climate disclosures for large companies, could offer synergistic benefits for the building stock. Voluntary measures, such as the UK Green Building Council Net Zero commitment, work with the grain of organisational commitments [75]. The middle actors we interviewed were sensitive to these common opportunities and situated variations; UK buildings policy could be too.

In addition, the findings of our pilot helped us reflect further on the Middle-Out Perspective. The framework helped identify where the middle actors in our study could act and where they felt they cannot because systemic barriers stand in their way of influencing decision-making. It showed how a sensitivity to circumstance is vital for these middleacting experts and how this can create magnifying effects of change for them, catalysing other actors. Our findings indicate how the ecology of actors in low-carbon buildings is dynamic and that the nature of the "middle" may be expanding. This includes actors who do not necessarily meet each other but who still respond to each other's concerns and hence also exercise "sideways" influences on agency and capacity. It may also be the case that different types of actor are relevant at different stages of low-carbon projects, as suggested by studies in the domestic building sector [67], and this would merit future research.

Given the relatively small number of interviews in this study, further work is needed to test the findings amongst a wider set of actors and beyond the two sub-sectors studied here. Research could further test the boundaries separating top, bottom, and middle actors, and their shifting ecology in the light of significant changes in policy and the UK economy arising from Net Zero and the pressures of the pandemic. The location of boundaries between actors and intermediaries would benefit exploration, and indeed how changes in current sustainability debates might move professionals from one to the other. Of particular interest are the nature of the overlaps between investors and funders with low-carbon building experts, and of other ESG issues with buildings, which we have not had a chance to explore in detail here. A further angle could be to explore practical policy suggestions 
which interact with organisational priorities and strategies to try to connect with the highly diverse non-domestic stock in the UK.

Author Contributions: Conceptualisation, C.W., K.B.J. and D.K.; methodology, K.B.J.; validation, C.W., K.B.J. and D.K.; formal analysis, C.W., K.B.J. and D.K.; investigation, C.W. and D.K.; writingoriginal draft preparation, C.W.; writing-review and editing, K.B.J. and D.K. All authors have read and agreed to the published version of the manuscript.

Funding: The interview data collection for this paper and initial analysis were funded by the Building Technology Accelerator (BTA) flagship within the Knowledge and Innovation Community on Climate (Climate-KIC) funded by the European Institute for Technology (EIT) under the Horizon 2020 framework of the European Union. The additional analysis and theoretical development specific to this research paper received no external funding.

Institutional Review Board Statement: The study was conducted according to the guidelines of the Declaration of Helsinki, and approved by the Research Ethics Committee of UCL's Bartlett School of Environment, Energy and Resources on 20 December 2019 (Reference Number Z6364106/2019/12/27).

Informed Consent Statement: Informed consent was obtained from all subjects involved in the study.

Acknowledgments: The authors would like to thank Ian Hamilton (UCL) and Paul Ruyssevelt (UCL) for their input and contribution to the overall non-domestic UK Building Market Brief pilot project, which also included contributions from Shih-Che Hsu (UCL). The interviews and related research design discussed in this paper were led mainly by the authors and were a discrete subset of the overall pilot project.

Conflicts of Interest: The authors declare no conflict of interest.

\section{References}

1. Palmer, J.; Terry, N.; Armitage, P. Building Performance Evaluation Programme: Findings from Non-Domestic Projects. Getting the Best from Buildings; Innovate UK: Swindon, UK, 2016.

2. Moezzi, M.; Janda, K.B. From "If Only" to "Social Potential” in Schemes to Reduce Building Energy Use. Energy Res. Soc. Sci. 2014, 1, 30-40. [CrossRef]

3. Department of Energy and Climate Change (DECC). What Are the Factors Influencing Energy Behaviours and Decision-Making in the Non-Domestic Sector? A Rapid Evidence Assessment; DECC: London, UK, 2012.

4. Stevenson, F. Embedding Building Performance Evaluation in UK Architectural Practice and Beyond. Build. Res. Inf. 2019, 47, 305-317. [CrossRef]

5. Lorch, R. Climate Policies for Buildings. Build. Res. Inf. 2017, 45, 475-477. [CrossRef]

6. Zou, P.X.W.; Xu, X.; Sanjayan, J.; Wang, J. Review of 10 Years Research on Building Energy Performance Gap: Life-Cycle and Stakeholder Perspectives. Energy Build. 2018, 178, 165-181. [CrossRef]

7. Fotiou, T.; de Vita, A.; Capros, P. Economic-Engineering Modelling of the Buildings Sector to Study the Transition towards Deep Decarbonisation in the EU. Energies 2019, 12, 2745. [CrossRef]

8. D'Agostino, D.; Zangheri, P.; Castellazzi, L. Towards Nearly Zero Energy Buildings in Europe: A Focus on Retrofit in NonResidential Buildings. Energies 2017, 10, 117. [CrossRef]

9. Cohen, R.; Austin, B.; Bannister, P.; Bordass, B.; Bunn, R. How the Commitment to Disclose In-Use Performance Can Transform Energy Outcomes for New Buildings. Build. Serv. Eng. Res. Technol. 2017, 38, 711-727. [CrossRef]

10. Climate Change Committee. The Sixth Carbon Budget: The UK's Path to Net Zero; Climate Change Committee: London, UK, 2020.

11. Sánchez Cordero, A.; Gómez Melgar, S.; Andújar Márquez, J.M. Green Building Rating Systems and the New Framework Level(s): A Critical Review of Sustainability Certification within Europe. Energies 2019, 13, 66. [CrossRef]

12. UK Green Building Council. Net Zero Carbon Buildings: A Framework Definition; UKGBC: London, UK, 2019.

13. Skanska. Skanska Tightens Its Climate Target. PR Newswire 2021. Available online: https://www.prnewswire.com/newsreleases/skanska-tightens-its-climate-target-301378368.html (accessed on 27 September 2021).

14. Greater London Authority (GLA). The London Plan; GLA: London, UK, 2021.

15. Janda, K.B.; Parag, Y. A Middle-out Approach for Improving Energy Performance in Buildings. Build. Res. Inf. 2013, 41, 39-50. [CrossRef]

16. Parag, Y.; Janda, K.B. More than Filler: Middle Actors and Socio-Technical Change in the Energy System from the "Middle-Out". Energy Res. Soc. Sci. 2014, 3, 102-112. [CrossRef]

17. Building Market Briefs: Climate-KIC. Available online: https://www.climate-kic.org/eit-climate-kic-insights/series/buildingmarket-briefs / (accessed on 24 November 2021).

18. Janda, K.B. Buildings Don't Use Energy: People Do. Archit. Sci. Rev. 2011, 54, 15-22. [CrossRef] 
19. Andrews, R.N.L.; Johnson, E. Energy Use, Behavioral Change, and Business Organizations: Reviewing Recent Findings and Proposing a Future Research Agenda. Energy Res. Soc. Sci. 2016, 11, 195-208. [CrossRef]

20. Cole, R.J. Motivating Stakeholders to Deliver Environmental Change. Build. Res. Inf. 2011, 39, 431-435. [CrossRef]

21. Department for Business, Energy \& Industrial Strategy (BEIS). Building Energy Efficiency Survey; Department for Business, Energy \& Industrial Strategy: London, UK, 2016.

22. Boyd, P.; Schweber, L. Unintended Consequences: Institutional Artefacts, Closure Mechanisms and the Performance Gap. Build. Res. Inf. 2018, 46, 10-22. [CrossRef]

23. Janda, K.B. Building Communities and Social Potential: Between and beyond Organizations and Individuals in Commercial Properties. Energy Policy 2014, 67, 48-55. [CrossRef]

24. Cass, N. Energy-Related Standards and UK Speculative Office Development. Build. Res. Inf. 2018, 46, 615-635. [CrossRef]

25. Cass, N.; Shove, E. Standards? Whose Standards? Archit. Sci. Rev. 2018, 61, 272-279. [CrossRef]

26. Gabe, J. Successful Greenhouse Gas Mitigation in Existing Australian Office Buildings. Build. Res. Inf. 2016, 44, 160-174. [CrossRef]

27. Bordass, B.; Cohen, R.; Bannister, P. Design for Performance UK Commitment Agreements: Making Measured Energy in-Use the Objective for New Office Buildings; Feasibility Study Final Report; Better Buildings Partnership: London, UK, 2016; p. 27.

28. Department for Business, Energy \& Industrial Strategy. Introducing a Performance-Based Policy Framework in Large Commercial and Industrial Buildings; BEIS: London, UK, 2021.

29. Department for Business, Energy \& Industrial Strategy. Non-Domestic Private Rented Sector Minimum Energy Efficiency Standards: EPC B Implementation; BEIS: London, UK, 2021.

30. Ameli, N.; Drummond, P.; Bisaro, A.; Grubb, M.; Chenet, H. Climate finance and disclosure for institutional investors: Why transparency is not enough. Clim. Chang. 2020, 160, 565-589. [CrossRef]

31. Cooremans, C. Make it strategic! Financial investment logic is not enough. Energy Effic. 2011, 4, 473-492.

32. Coleman, S.; Robinson, J.B. Introducing the qualitative performance gap: Stories about a sustainable building. Build. Res. Inf. 2018, 46, 485-500. [CrossRef]

33. Janda, K.B.; Bright, S.; Patrick, J.; Wilkinson, S.; Dixon, T.J. The Evolution of Green Leases: Towards Inter-Organizational Environmental Governance. Build. Res. Inf. 2016, 44, 660-674. [CrossRef]

34. Deline, M.B. Energizing Organizational Research: Advancing the Energy Field with Group Concepts and Theories. Energy Res. Soc. Sci. 2015, 8, 207-221. [CrossRef]

35. Axon, C.J.; Bright, S.J.; Dixon, T.J.; Janda, K.B.; Kolokotroni, M. Building Communities: Reducing Energy Use in Tenanted Commercial Property. Build. Res. Inf. 2012, 40, 461-472. [CrossRef]

36. Badi, S. Public Sustainable-Energy Requirements and Innovation in UK PFI School Projects. Constr. Manag. Econ. 2017, 35, 218-238. [CrossRef]

37. Moncaster, A.M.; Simmons, P. Policies and Outcomes for UK Sustainable Schools. Build. Res. Inf. 2015, 43, 452-464. [CrossRef]

38. Dasgupta, A.; Prodromou, A.; Mumovic, D. Operational versus Designed Performance of Low Carbon Schools in England: Bridging a Credibility Gap. HVACR Res. 2012, 18, 37-50. [CrossRef]

39. Godoy-Shimizu, D.; Armitage, P.; Steemers, K.; Chenvidyakarn, T. Using Display Energy Certificates to Quantify Schools' Energy Consumption. Build. Res. Inf. 2011, 39, 535-552. [CrossRef]

40. Hong, S.-M.; Paterson, G.; Mumovic, D.; Steadman, P. Improved Benchmarking Comparability for Energy Consumption in Schools. Build. Res. Inf. 2013, 42, 47-61. [CrossRef]

41. Mallaburn, P. A New Approach to Non-Domestic Energy Efficiency Policy. A Report for the Committee on Climate Change; UCL Energy Institute, University College London: London, UK, 2016.

42. Yeatts, D.E.; Auden, D.; Cooksey, C.; Chen, C.-F. A Systematic Review of Strategies for Overcoming the Barriers to Energy-Efficient Technologies in Buildings. Energy Res. Soc. Sci. 2017, 32, 76-85. [CrossRef]

43. Galvin, R.; Terry, N. Selling Energy Savings in the United Kingdom: A Case Study of Top-down pro-Environmental Behaviour Change in Commercial Office Buildings. Energy Res. Soc. Sci. 2016, 11, 155-163. [CrossRef]

44. Zapata-Lancaster, G.; Tweed, C. Designers' Enactment of the Policy Intentions. An Ethnographic Study of the Adoption of Energy Regulations in England and Wales. Energy Policy 2014, 72, 129-139. [CrossRef]

45. Grandclément, C.; Karvonen, A.; Guy, S. Negotiating Comfort in Low Energy Housing: The Politics of Intermediation. Energy Policy 2015, 84, 213-222. [CrossRef]

46. Kivimaa, P.; Boon, W.; Hyysalo, S.; Klerkx, L. Towards a Typology of Intermediaries in Sustainability Transitions: A Systematic Review and a Research Agenda. Res. Policy 2019, 48, 1062-1075. [CrossRef]

47. Van Lente, H.; Hekkert, M.; Smits, R.; van Waveren, B. Roles of systemic intermediaries in transition processes. Int. J. Innov. Manag. 2003, 7, 247-279. [CrossRef]

48. Bordass, B.; Leaman, A. A New Professionalism: Remedy or Fantasy? Build. Res. Inf. 2013, 41, 1-7. [CrossRef]

49. Killip, G.; Fawcett, T.; Janda, K.B.; Beillan, V.; Nosperger, S. Building Expertise: Industry Responses to the Low-Energy Housing Retrofit Agenda in the UK and France. In Proceedings of the ECEEE Summer Study Panel 1: Foundations of Future Energy Policy, Hyères, France, 3-8 June 2013; pp. 77-86.

50. Wade, F.; Murtagh, N.; Hitchings, R. Managing Professional Jurisdiction and Domestic Energy Use. Build. Res. Inf. 2018, 46, 42-53. [CrossRef] 
51. Janda, K.B.; Killip, G.; Fawcett, T. Reducing Carbon from the "Middle-Out": The Role of Builders in Domestic Refurbishment. Buildings 2014, 4, 911-936. [CrossRef]

52. Killip, G. Products, Practices and Processes: Exploring the Innovation Potential for Low-Carbon Housing Refurbishment among Small and Medium-Sized Enterprises (SMEs) in the UK Construction Industry. Energy Policy 2013, 62, 522-530. [CrossRef]

53. Palm, J.; Reindl, K. Understanding Energy Efficiency in Swedish Residential Building Renovation: A Practice Theory Approach Energy Res. Soc. Sci. 2016, 11, 247-255. [CrossRef]

54. Wade, F.; Hitchings, R.; Shipworth, M. Understanding the Missing Middlemen of Domestic Heating: Installers as a Community of Professional Practice in the United Kingdom. Energy Res. Soc. Sci. 2016, 19, 39-47. [CrossRef]

55. Frick, V.; Seidl, R.; Stauffacher, M.; Moser, C. Promoting Energy-Saving Behaviour: Formal Social Groups as Promising Middle Actors for Municipal Interventions. Energy Effic. 2017, 10, 1539-1551. [CrossRef]

56. Martiskainen, M. The Role of Community Leadership in the Development of Grassroots Innovations. Environ. Innov. Soc. Transit. 2017, 22, 78-89. [CrossRef]

57. Goulden, M.; Spence, A. Caught in the Middle: The Role of the Facilities Manager in Organisational Energy Use. Energy Policy 2015, 85, 280-287. [CrossRef]

58. Gluch, P.; Bosch-Sijtsema, P. Conceptualizing Environmental Expertise through the Lens of Institutional Work. Constr. Manag. Econ. 2016, 34, 522-535. [CrossRef]

59. Simpson, K.; Janda, K.B.; Owen, A. Preparing 'Middle Actors' to Deliver Zero-Carbon Building Transitions. Build. Cities 2020, 1, 610. [CrossRef]

60. Dexter, L.A. Elite and Specialized Interviewing; ECPR Press: Colchester, UK, 2006.

61. Buchanan, D.; Boddy, D.; McCalman, J. Getting in, getting on, getting out, and getting back. In Doing Research in Organizations; Bryman, A., Ed.; Routledge: London, UK, 2013; pp. 53-67.

62. Audenhove, L.V. Expert Interviews and Interview Techniques for Policy Analysis; Vrije Universiteit Brussel: Brussels, Belgium, 2007; Available online: https:/ / www.ies.be/files/060313\%20Interviews_VanAudenhove.pdf (accessed on 9 November 2021).

63. Fylan, F. Semi Structured Interviewing. In A Handbook of Research Methods for Clinical and Health Psychology; Miles, J., Gilbert, P., Eds.; Oxford University Press: New York, NY, USA, 2005; pp. 65-77.

64. Braun, V.; Clarke, V. Using thematic analysis in psychology. Qual. Res. Psychol. 2006, 3, 77-101. [CrossRef]

65. Fereday, J.; Muir-Cochrane, E. Demonstrating rigor using thematic analysis: A hybrid approach of inductive and deductive coding and theme development. Int. J. Qual. Methods 2006, 5, 80-92. [CrossRef]

66. King, G.; Keohane, R.O.; Verba, S. Designing Social Inquiry: Scientific Inference in Qualitative Research; Princeton University Press: Princeton, NJ, USA, 1994.

67. Martiskainen, M.; Kivimaa, P. Creating innovative zero carbon homes in the United Kingdom-Intermediaries and champions in building projects. Environ. Innov. Soc. Transit. 2018, 26, 15-31. [CrossRef]

68. Mallaburn, P.; Azhari, R.; Fawcett, T.; Topouzi, M. Australian Non-Domestic Buildings Policy as an International Exemplar. Build. Cities 2021, 2, 318-335. [CrossRef]

69. Brand, R.; Karvonen, A. The ecosystem of expertise: Complementary knowledges for sustainable development. Sustain. Sci. Pract. Policy 2007, 3, 21-31. [CrossRef]

70. Bull, R.; Janda, K.B. Beyond feedback: Introducing the 'engagement gap' in organizational energy management. Build. Res. Inf. 2018, 46, 300-315. [CrossRef]

71. Kesidou, S.L.; Sorrell, S. Low-carbon innovation in non-domestic buildings: The importance of supply chain integration. Energy Res. Soc. Sci. 2018, 45, 195-213. [CrossRef]

72. Khosla, R.; Dukkipati, S.; Dubash, N.K.; Sreenivas, A.; Cohen, B. Towards Methodologies for Multiple Objective-Based Energy and Climate Policy. Econ. Political Wkly. 2015, 50, 49-59.

73. Willan, C.; Hitchings, R.; Ruyssevelt, P.; Shipworth, M. Talking about targets: How construction discourses of theory and reality represent the energy performance gap in the United Kingdom. Energy Res. Soc. Sci. 2020, 64, 247-255. [CrossRef]

74. Bordass, B. Metrics for energy performance in operation: The fallacy of single indicators. Build. Cities 2020, 1, 260-276. [CrossRef]

75. Janda, K.B.; Kenington, D.; Ruyssevelt, P.; Willan, C. Towards Net Zero in UK Commercial Real Estate: Key Information, Perspectives and Practical Guidance; HSBC Centre of Sustainable Finance: London, UK, 2021. 